\title{
The 5 Hallmarks of Biomaterials Success: An Emphasis on Orthopaedics
}

\author{
Dustin L. Williams ${ }^{1,2}$, Brad M. Isaacson ${ }^{3,4}$ \\ ${ }^{1}$ Bone \& Joint Research Laboratory, Department of Veterans Affairs, Salt Lake City, USA \\ ${ }^{2}$ Department of Orthopaedics, University of Utah, Salt Lake City, USA \\ ${ }^{3}$ The Henry M. Jackson Foundation for the Advancement of Military Medicine, Bethesda, USA \\ ${ }^{4}$ The Center for Rehabilitation Sciences Research, Department of Physical Medicine and Rehabilitation, \\ Uniformed Services University of Health Sciences, Bethesda, USA \\ Email: dustin.williams@utah.edu, brad.isaacson.ctr@usuhs.edu
}

Received 21 November 2013; revised 25 January 2014; accepted 19 February 2014

Copyright (C) 2014 by authors and Scientific Research Publishing Inc.

This work is licensed under the Creative Commons Attribution International License (CC BY).

http://creativecommons.org/licenses/by/4.0/

(c) (i) Open Access

\begin{abstract}
Over the past 200 years, there has been significant advancements in the fields of bioengineering and orthopaedics. Investigators, clinicians and manufactures are learning that the success of implant systems is not limited to a single factor, but a combination of variables that must work in unison to provide stability and high survivorship. Innovations continue to advance these fields and include: biomimetic alterations, three-dimensional, patient-specific reconstructions and novel coatings to mitigate aseptic loosening or other pathologies. However, implant systems continue to fail in clinical practice since they do not adhere to key fundamental principles. Therefore, this article is intended to highlight 5 hallmarks of biomaterials that should be considered during design, surgery, and post-operative rehabilitation.
\end{abstract}

\section{Keywords}

Biomaterials; Orthopaedics; Implant; Bone; Biofilm

\section{Introduction}

Much of what is known about biomaterials derived from non-biomedical engineering endeavors. For example, during World War II pilots who sustained windshield shrapnel in their eyes from combat experienced a minimal foreign body reaction. Thus Dr. Harold Ridley investigated polymethylmethacrylate (PMMA) as a biocompatible material for lens replacement [1]. Similarly, the large-scale production of titanium for jet aircrafts prompted researchers to investigate its use as a biomaterial (due to its excellent mechanical properties and resistance to 
corrosion [2] [3]).

In the mix of the war, Bothe et al. published results suggesting for the first time that bone may fuse with titanium [4]. Eleven years later, Leventhal published further results demonstrating minimal soft tissue reaction to titanium and its potential use as a metal in orthopaedic applications [5]. Approximately the same time as Leventhal, Per-Ingvar Brånemark independently observed that bone attached to titanium chambers that were used to visualize blood cell formation in rabbit marrow. However, it is Brånemark’s research with titanium and bone integration that is mostly recognized as contributing to the current understanding of "osseointegration" [6]. From this work, titanium has become commonplace in dental implants, total joint replacements, fracture fixation plates, intramedullary nails and external fixators [7] [8].

Prior to the use of titanium as an orthopaedic implant, various other metals-including stainless steel and Vitallium ${ }^{\mathrm{TM}}$ - were used for fracture fixation plates [5] and dental implants [9] [10], but these metals were not investigated as a substitute for hip replacements until the 1940s [11]. Stemming from the work by Glück in 1891, who used ivory as a ball and socket joint to create a hip fixation implant, Moore was the first surgeon to implant a total hip fixation device made of Vitallium ${ }^{\mathrm{TM}}$ [12]. Sir John Charnley then revolutionized the design by developing a separate acetabular cup and femoral component made of Teflon ${ }^{\mathrm{TM}}$ and titanium respectively, which were cemented into place with PMMA. The use of Teflon ${ }^{\mathrm{TM}}$ by Charnley marked one of the early uses of a polymer in orthopaedic implants. However, because of premature wear [13]-[15], Teflon ${ }^{\mathrm{TM}}$ was found to not be a suitable material for acetabular components, and by 1962 was replaced by ultra-high-molecular-weight-polyethylene (UHMWPE) since it produced fewer wear particles during cyclic loading [13] [16]. This pioneering work by Charnley prompted joint arthroplasty, which once was a rare procedure, to become commonplace [17]. Total knee arthroplasty (TKA) in particular, is one of the most frequent elective surgical procedures and accounts for 450,000 cases in the United States annually [18].

The success of orthopaedic implants (similar to those designed by Brånemark, Glück, Charnley, etc.) cannot be attributed solely to good intuition or the material type alone. While titanium is a preferred biomaterial for many orthopaedic applications, additional factors significantly impact implant survivorship. Therefore, this article is intended to provide an overview of critical principles and will discuss what we define as the 5 hallmarks of orthopaedic biomaterials success: 1) biocompatibility, 2) physician technique, 3) design, 4) mechanical stability/initial fixation, and 5) infection prevention.

\subsection{Biocompatibility}

Over the past two decades, several definitions of "biocompatibility" have been proposed. Williams stated that "biocompatibility is the ability of a material to perform with an appropriate host response in a specific application" [19]. Mardis and Kroeger defined biocompatibility as being "the utopian state where a biomaterial presents an interface with a physiologic environment without the material adversely affecting the environment or the environment adversely affecting the material” [20]. These definitions have provided general guidelines for which researchers have compared the response of host tissue to biomaterials, and vise versa. However, as discoveries continue to be made, these definitions must be modified to conform to the ever-increasing understanding of biomaterial-host interactions.

Although no material known to man is completely biocompatible (i.e. no wound will heal in the same manner when a biomaterial is present than if it is not), it may be that our understanding of protein-surface interactions contributes most significantly to how we define biocompatibility. More specifically, shortly after implanting a biomaterial in the body, a conditioning film containing small molecules including water, electrolytes, cholesterol, complement, vitamins, lipids and proteins (such as albumin, IgG, fibronectin, fibrinogen, laminin, collagen and of interest to orthopaedics, osteopontin) forms on the surface of the implant long before cells are present and reach a state of equilibrium thereon [21]-[23]. This layer is dynamic and ever changing due to the differential diffusion and mass transport of these molecules/cells toward the implant surface. Competitive binding occurs on the surface due to the affinity of the molecules/cells towards the surface. Thus, it can be hypothesized that cells never "see" the entire surface of a biomaterial, but more correctly respond to and interact with the conditioning film that already developed in situ. The same would be true for bacteria that might be present near the implant surface (discussed in subsequent sections).

Attachment-dependent cells secure themselves to these proteins or protein matrices using integrin receptors, thus this conditioning film becomes very important in the reaction of cells to the surface of an orthopaedic bioma- 
terial. This interface is what has prompted researchers to investigate protein-preconditioned surfaces of biomaterials [24]. Importantly, this conditioning film plays a significant role in biocompatibility because of the conformational changes that occur to adsorbed proteins, which often result in proinflammatory signals by the host immune system. As proteins adsorb to a biomaterial surface, they often change conformation and expose epitopes that are not typically identified as self-produced by the body's immune cells [23]. Immune cells then react as they detect what once were normal physiological proteins as foreign body materials. The result of this effect may be a cascade of blood coagulation and/or chronic inflammation, which can further lead to occlusion of nutrients, changes in oxygen tension, excessive fibrous capsule formation [25] and most importantly rejection of an implant system.

The extent of protein deformation and the assortment of proteins that adsorb onto an orthopaedic implant vary based on the material type [23] [26] [27]. For example, in an attempt to make metal surfaces more "passive," i.e. more resistant to corrosion, chemical treatments are often added during the manufacturing process. Passivation with nitric acid of stainless steel devices creates a less reactive oxide layer for enhanced biocompatibility. However, passivation also has one added benefit; it serves as a means for removing foreign material from the surface of metals such as machining oil and bacteria, (including bacteria that reside in a biofilm) [28]-[31]. However, our team recently grew biofilms of Staphylococcus epidermidis on the surface of titanium metal and found that despite being sonicated in detergent, passivated with nitric acid, rinsed with copious amounts of water and autoclaved, the surface of titanium still contained biofilm on the surface in over $30 \%$ of cases (unpublished data). Thus, if bacteria remain on the surface of an implant, dead or alive, their foreign materials and endotoxins may foster inflammation and lead to subsequent implant failure.

In the case of titanium, these specific metals naturally develop an oxide layer on the surface [32] which helps chemically bond the surface with the osseous cells during cementless skeletal fixation. While this is generally desired, in specific applications, long chain alcohol treatment of titanium may be used to make the surface more hydrophobic [33]; generally, hydrophilic surfaces have greater biocompatibility due to water retention at the surface. Therefore, a unique surface may be developed if only transient bone attachment is desired. Hydrophobic surfaces are also more apt to attract the adsorption of albumin, the most abundant protein in plasma that contains several hydrophobic residues. It is almost always undesirable to have albumin on the surface of an orthopaedic implant due to the inability of attachment-dependent cells to adhere to it. If albumin is the dominating protein at the surface, greater fibrous capsule formation occurs and there is problems maintaining a durable cementless skeletal fixation. An implant which does not remain fixed at the bone-implant construct may generate more wear particulate and this leads to bone loss and implant loosening [34] [35]. Taken together, any change in the treatment/production of orthopaedic implants should be noted and the success rate of the implants documented to determine the effect of treatments and modifications.

\subsection{Physician Techniques}

Perhaps the most difficult measure for predicting the success of an implanted device is the variation of physician technique. Multiple instruments have been designed to optimize the approach to total joint replacements (TJRs), however, the aspect of human variability will never be entirely removed. Importantly, it should be recognized that despite a surgeon's best efforts, the dissimilarity of each patient's bone quality, porosity, vasculature and lifestyle play a significant role in the success of an implant [36]-[39].

One option for reducing host rejection of orthopaedic implants requires careful surgical procedures and controlled drilling techniques. Attention must be paid to the temperature of the implantation site since excessive heat generated from frictional forces may lead to necrosis of the host bed-thus increasing the likelihood of scar tissue formation, which lacks the tensile strength of normal connective tissue and cannot sustain the loads exerted on an orthopedic implant [40]. Once a soft-tissue reaction has occurred, the healing process resembles pseudarthrosis, and repair is unlikely [41]. Determining the critical temperature of bone necrosis also compounds this problem. Literature indicates that that temperatures must be maintained below $56^{\circ} \mathrm{C}$ since alkaline phosphatase (AP) is denatured at this temperature threshold [42]. AP is an enzyme produced during osteogenesis and may be an important phosphate transporter [43]. However, during conventional surgery, temperatures may exceed $65^{\circ} \mathrm{C}[44]$ and have been recorded as high as $89^{\circ} \mathrm{C}[41]$.

\subsection{Design}

An ideal implant design is one that models the anatomical geometry of living tissue and contains the same ratios 
of physiological byproducts. However, tissue engineering models are still in their infancy and will require years of research prior to widespread usage during orthopaedic applications. Biocompatible metals and non-biodegradable polymers, on the other hand, are readily available and have been used for hundreds of years [45]. Despite the host of available bioactive agents which may be deposited to the exterior of a material surface, the fixation of all orthopedic implants depends on establishing a strong mechanical interlock with the bone, proper surgical technique, and the implant design altogether [46].

Because TJRs are subjected to high cyclic loads, clinical reports have indicated that approximately $25 \%$ of surgical implants fail from aseptic loosening and have been attributed to wear from articular bearings [47]. Altered loading patterns on newly implanted TJRs may compromise the material integrity since hip contact forces may exceed $409 \%$ the body weight with disturbed gait patterns [48]. Abnormally high non-physiological loads may not be supported and wear improperly given that hip and knee joints are cyclically loaded approximately 2 $\times 10^{6}$ times annually [3].

To prevent implant loosening and ensure firm skeletal attachment, the orthopaedic industry has looked to porous coated surface treatments. Increasing implant roughness has improved the longevity of TJRs, but has also raised concerns with coating disassociation at the bone-implant interface. Metal particulate released from orthopaedic implants have been noted to appear in the urine, blood, and lungs remote from an implantation site [49]; and some of the metal alloys may be toxic and dissolve in the body fluids [50]. While there has not be a direct association with detached coatings and health problems due to underpowered studies [51], high aggregations of metal from orthopaedic implants may be linked with pathological diseases such as marrow fibrosis [52], cystic destruction of bone [52], granulomatosis [53], necrosis of the bone marrow [54], neoplasia [55]-[57], sarcoma [58]-[60], bone resorption [61], cardiomyopathy [62] and thyroid dysfunction [62].

\subsection{Mechanical Stability/Initial Fixation}

Attaining a strong skeletal interlock at the bone-implant interface is a prerequisite for long-term implant function and stability [63] [64]. While PMMA may be used for patients with inadequate bone stock, evidence of monomer leakage or exothermic curing reactions [41] [65] [66] are some reasons why some patients advocate for osseointegration procedures. Immediate weight bearing in joint arthroplasty is often advocated and does not compromise the integrity of the periprosthetic bone as long as micromotion is carefully controlled [64] [67]-[71].

Despite the signs of adequate implant "fit and fill", "it is evident that there must always be some movement between and artificial joint component and bone, even if its amplitude is minuscule and the precise site of its occurrence obscure [46]." However, the complete lack of integration between the host bone and implant leads to excessive micromotion and premature failure. This condition does not provide the skeletal attachment required for secondary implant stability (which results from bone remodeling that occurs over time [72]) and does not have the structural integrity to withstand the dynamic mechanical forces from during ambulation [73]. While initial implant fixation is required to prevent micromotion and fibrous encapsulation [7] [69] [74]-[80], the long-term success of orthopaedic implants requires firm skeletal attachment, which may require up to 9 months in human cancellous bone [74]. Therefore, the primary step in initial implant fixation is to minimize gaps greater than $50 \mu \mathrm{m}$ since this has been noted to be unstable and prevents integration [7].

Roughness, porosity and surface topography may be specifically tailored based on the application and will impact the host response to an implant [76] [81] More specifically, the implant surface is vital in cementless skeletal fixation, as specific profiles influence osteoblast and osteoclast attachment and metabolism [82]. Boyan et al. previously noted that implant surfaces should be between $4-7 \mu \mathrm{m}$ in roughness to ensure proper osteoblast cuboid morphology [83]; while others in the peer-reviewed literature note that skeletal fixation is most effective with porous implants in the 50 - $400 \mu \mathrm{m}$ range [84] and with roughened surfaces. This hallmark has been demonstrated by observing that osteoblasts seated on roughened surfaces have increased proliferation and in vivo animal models revealed that textured surfaces required higher removal torques compared with smooth controls during bone-implant removal [76].

\subsection{Infection Prevention}

Orthopaedic implant-related infections are catastrophic to patients and physicians. These occurrences are often accompanied by extensive and expensive strategies of debridement, implant removal, antibiotic therapy and rehabilitation. The severity and concern of implant-related infections has been amplified in the past several dec- 
ades with an increased understanding of bacterial biofilms that have the potential to form on the surface of implanted materials [85]-[93]. Biofilms are communities of bacteria that have the ability to communicate, transfer genetic material, protect themselves with secreted polymeric substances that encapsulate the community in a hydrated matrix and preferentially adhere to solid surfaces [86] [87] [90] [93]. Biofilms may serve as reservoirs of infection in patients who have indwelling devices [91]. More specifically, as antibiotics are administered, planktonic cells within the body may be killed and alleviate symptoms of infection short term. However, once antibiotic treatment has been discontinued, infection may recur. This cycle may continue for years until a biofilm-ridden device or tissue is removed [89] [91] [94] [95].

In light of the ever-present risk of biofilm implant-related infection, emphasis is placed on rigorous sterilization techniques for instrumentation and implants prior to surgery [86]. Yet despite these efforts, infection remains a significant problem. Adherence of bacteria to orthopaedic devices begins with contamination of the surgical site or implant. This contamination may come from multiple sources, the most likely of which is the patient, surgeon, or healthcare worker. The surrounding environment, such as air from filtration systems, may likewise contain bacteria. As noted by Williams and Costerton [96], skin preps have the ability to remove the top few layers of skin and kill approximately $99.9 \%$ of bacteria, i.e., a $3 \log _{10}$ reduction [96]. However, mature bacterial biofilms may reside up to 7 layers deep in human skin [97]. Thus, when an incision is made, contamination of tissues may follow despite extensive treatment with surgical prep packs. In addition, bacteria may be released from the nose, mouth or skin of surgeons, a patient or healthcare workers in an operating room. Ventilation systems may also transport bacteria from one room to another even in laminar flow surgical suites.

Once an incision site has been contaminated, microorganisms reproduce in high quantity. The adhesion process becomes almost irreversible as extracellular polymeric substances act as an adhesive between the biofilm and an implant surface [98]. Bacteria express membrane adhesins, which help to prevent phagoctyosis by neutrophils and adhere to host cells, thus increasing their virulence. One of the most difficult aspects of orthopaedic device-related infections is the diagnosis of biofilm-related infections. For example, Sir John Charnley, credited with the creation of the artificial hip, was unaware of biofilm formation in the early 1970s and noted "a rather high incidence of manifestations of infections, months or years after the implant was made... which might be blood-borne in origin or even the result of chemical reaction [99]." Failure of orthopedic implants is often misclassified as aseptic because due to the lack of clinical evidence [100]. However, new promising technologies involve 16s DNA sequencing to identify non-culturable bacteria, may improve diagnosis and increase implant success [101]-[103].

Once a medical device is placed in vivo, biofilms may cause damage by inducing a significant inflammatory response and colonizing the host tissue [86]. Biofilm-related infections may develop months or years after implantation and often require excision of necrotic bone or implant removal [86]. Once the onsite of infection has been determined, antibiotics may be administered, but have marginal efficacy since biofilms require exponentially higher antibiotic concentrations [104] [105]. It has been reported that biofilms are between 500 - 5000x more difficult to eradicate because they are in a non-planktonic form [86] [99] [106] [107].

In short, understanding the development of sessile, biofilm communities is a fundamental factor for determining how to prevent biofilm implant-related infections from occurring. In an attempt to prevent these infections, multiple technologies have been developed including: passive and active release antimicrobial coatings, antimicrobial loaded bone cements and beads, antimicrobial loaded sleeves for fracture fixation plates, and novel antimicrobial compounds that are specifically synthesized to be active against biofilms [108]-[117].

\section{Conclusion}

Orthopaedic devices are expected to be implanted at much higher rates in the upcoming decades since individuals are living longer and still demand the same quality of life. Successful procedures will continue to improve based on optimized surgical technique and advanced implant designs/coatings. However, to further increase the likelihood for long-term implant survivorship, the 5 hallmarks for biomaterials noted above should be considered. While this narrative is intended to provide an overview, the authors recognize that there is not a perfect roadmap to prevent early implant loosening, infection or other failures. Adherence to these principles may not guarantee success, however, ignoring these principles will likely yield future complications. In conclusion, future designs should emphasize infection prevention, early mechanical stability and geometry which ensure proper fit and fill. 


\section{Acknowledgements}

This material is based upon work supported by the Department of the US Army under award numbers W81XWH-12-2-0017 to the Henry M. Jackson Foundation for the Advancement of Military Medicine, Inc. (Fort Detrick, MD) the Center for Rehabilitation Science Research NF90UG, (Bethesda, MD). Content was also supported by award number R01AR057185 from the National Institute of Arthritis and Musculoskeletal and Skin Diseases.

\section{References}

[1] Apple, D.J. and Sims, J. (1996) Harold Ridley and the Invention of Intraocular Lens. Survey of Ophthalmology, 40, 279-292. http://dx.doi.org/10.1016/S0039-6257(96)82003-0

[2] Agins, H.J., Alcock, N.W., Bansal, M., Salvati, E.A., Wilson, P.D., Pellicei, P.M., et al. (1988) Metallic Wear in Failed Titanium-Alloy Total Hip Replacements. The Journal of Bone \& Joint Surgery, 70-A, 347-356.

[3] Tummler, H.-P., Thull, R. and Schaldach, M. (1982) The Mechanism of Repassivation and the Concentration of Corrosion Products Shown on TIALV. Proceedings of the World Congress on Medical Physics and Biomedical Engineering, 13th International Conference on Medical and Biological Engineering, 6th International Conference on Medical Physics, Congress Centrum Hamburg, Germany, 3-11.

[4] Bothe, R.T., Beaton, L.E. and Davenport, H.A. (1940) Reaction of Bone to Multiple Metallic Implants. Surgery, Gynecology and Obstetrics, 71, 598-602.

[5] Leventhal, G.S. (1951) Titanium, a Metal for Surgery. Journal of Bone and Joint Surgery, 33A, 473-474.

[6] Brånemark, P.-I. (2005) The Biologic Origin of Osseointegration. The Osseointegration Book: From Calvarium to Calcaneus. Quintessence Books, Berlin, 22.

[7] Bloebaum, R.D., Bachus, K.N., Momberger, N.G. and Hofmann, A.A. (1994) Mineral Apposition Rates of Human Cancellous Bone at the Interface of Porous Coated Implants. Journal of Biomedical Materials Research, 28, 537-544. http://dx.doi.org/10.1002/jbm.820280503

[8] Bloebaum, R.D., Willie, B.M., Mitchell, B.S. and Hofmann, A.A. (2007) Relationship between Bone Ingrowth, Mineral Apposition Rate, and Osteoblast Activity. Journal of Biomedical Materials Research, Part A, 81, 505-514. http://dx.doi.org/10.1002/jbm.a.31087

[9] Gore, D., Frazer, R., Kovarik, R. and Yepes, J. (2005) Vitallium. Journal of Long-Term Effects of Medical Implants, 15, 673-686. http://dx.doi.org/10.1615/JLongTermEffMedImplants.v15.i6.90

[10] Davis, J.R. (2006) Metallic Materials. In: Davis, J.R., Ed., Handbook of Materials for Medical Devices, ASM International, Materials Park, 31.

[11] Gore, D.R., Frazer, R.Q., Kovarik, R.E. and Yepes, J.F. (2005) Vitallium. Journal of Long-Term Effects of Medical Implants, 15, 673-686. http://dx.doi.org/10.1615/JLongTermEffMedImplants.v15.i6.90

[12] Gomez, P.F. and Morcuende, J.A. (2005) Early Attempts at Hip Arthorplasty-1700s to 1950s. The Iowa Orthopaedic Journal, 25, 5-9.

[13] Charnley, J. (1966) Letter to the Editor. The Journal of Bone and Joint Surgery, 48-A, 819.

[14] Charnley, J. (1976) The Wear of Plastics Materials in the Hip-Joint. Plastics and Rubber, 1, 59-63.

[15] Charnley, J., Kamangar, A. and Longfield, M.D. (1969) The Optimum Size of Prosthetic Heads in Relation to the Wear of Plastic Sockets in Total Replacement of the Hip. Medical and Biological Engineering, 7, 31-39. http://dx.doi.org/10.1007/BF02474667

[16] Good, V.D., Clarke, I.C., Gustafson, G.A., Downs, B., Anissian, L. and Sorensen, K. (2000) Wear of Ultra-High Molecular Weight Polyethylene and Polytetrafluorethylene in a Hip Simulator. Acta Orthopaedica, 71, 365-369. http://dx.doi.org/10.1080/000164700317393358

[17] Kennedy, W.F., Roberts, C.G., Zuege, R.C. and Dicus, W.T. (1993) Use of Pulsed Electromagnetic Fields in Treatment of Loosened Cemented Hip Prostheses. A Double-Blind Trial. Clinical Orthopaedics and Related Research, 286, 198-205.

[18] Ilfeld, B.M., Mariano, E.R., Williams, B.A., Woodard, J.N. and Macario, A. (2007) Hospitalization Costs of Total Knee Arthroplasty with a Continuous Femoral Nerve Block Provided only in the Hospital versus on an Ambulatory Basis: A Retrospective, Case-Control, Cost-Minimization Analysis. Regional Anesthesia and Pain Medicine, 32, 4654.

[19] Williams, D.F. (2004) Definitions in Biomaterials. Proceedings of a Consensus Conference of the European Society for Biomaterials. March 2-5, 1986. In: Ratner, B.D., Hoffman, A.S., Schoen, F.J. and Lemons, J.E., Eds., Biomaterials 
Science: An Introduction to Materials in Medicine, 2 Edition, Academic Press, 2.

[20] Mardis, H.K. and Kroeger, R.M. (1988) Ureteral Stents. The Urologic Clinics of North America, 15, 471-479.

[21] Furno, F. and Bayston, R. (2008) Antimicrobial/Antibiotic (Infection Resistance) Materials. In: Wnek, G.E. and Bowlin, G.L., Eds., Encyclopedia of Biomaterials and Biomedical Engineering, Informa Healthcare, New York, 61.

[22] Koenig, A.L., Gambillara, V. and Grainger, D.W. (2002) Correlating Fibronectin Adsorption with Endothelial Cell Adhesion and Signaling on Polymer Substrates. Journal of Biomedical Materials Research Part A, 64, $20-37$.

[23] Thevenot, P., Hu, W. and Tang, L. (2008) Surface Chemistry Influences Implant Biocompatibility. Current Topics in Medicinal Chemistry, 8, 270-280. http://dx.doi.org/10.2174/156802608783790901

[24] Reid, G. (1999) Biofilms in Infectious Disease and on Medical Devices. International Journal of Antimicrobial Agents, 11, 223-226. http://dx.doi.org/10.1016/S0924-8579(99)00020-5

[25] Bruder, S.P., Fink, D.J. and Caplan, A.I. (1994) Mesenchymal Stem Cells in Bone Development, Bone Repair, and Skeletal Regeneration Therapy. Journal of Cellular Biochemistry, 56, 283-294.

http://dx.doi.org/10.1002/jcb.240560303

[26] Nygren, H. (1996) Initial Reactions of Whole Blood with Hydrophilic and Hydrophobic Titanium Surfaces. Colloids and Surfaces B, 6, 329-333. http://dx.doi.org/10.1016/0927-7765(96)01270-2

[27] Eriksson, C. and Nygren, H. (2001) Polymorphonuclear Leukocytes in Coagulating Whole Blood Recognize Hydrophilic and Hydrophobic Titanium Surfaces by Different Adhesion Receptors and Show Different Patterns of Receptor Expression. Journal of Laboratory and Clinical Medicine, 137, 296-302. http://dx.doi.org/10.1067/mlc.2001.114066

[28] Blumenfeld, T.J. and Bargar, W.L. (2006) Early Aseptic Loosening of a Modern Acetabular Component Secondary to a Change in Manufacturing. Journal of Arthroplasty, 21, 689-695. http://dx.doi.org/10.1016/j.arth.2005.10.010

[29] Bloebaum, R.D., Ferguson, R.P., Neff, C.M., Gorp, C.V., Woolley, D.L. and Hofmann, A.A. (2004) Bone Viability Determination in Human Cancellous Bone from Patients Undergoing Revision Hip Arthroplasty. The Journal of Arthroplasty, 19, 745-750. http://dx.doi.org/10.1016/j.arth.2004.03.008

[30] Campbell, P., Mirra, J. and Catelas, I. (2002) Histopathology of Tissues from Inter-Op Acetabular Sockets. 48th Annual Meeting of the Orthopaedic Research Society, Dallas.

[31] Spiegelberg, S., Deluzio, K. and Muratoglu, O. (2003) Extractable Residue from Recalled Inter-Op Acetabular Shells. 49th Annual Meeting of Orthopaedic Research Society, New Orleans.

[32] Aaron, R.K., Herr, H.M., Ciombor, D.M., Hochberg, L.R., Donoghue, J.P., Briant, C.L., et al. (2006) Horizons in Prosthesis Development for the Restoration of Limb Function. Journal of the American Academy of Orthopaedic Surgeons, 14, S198-S204.

[33] Nygren, H. (1996) Initial Reactions of Whole Blood with Hydrophilic and Hydrophobic Titanium Surfaces. Colloids Surf B: Biointerfaces, 6, 329-333. http://dx.doi.org/10.1016/0927-7765(96)01270-2

[34] Jacobs, J.J. (2001) What Are the Systemic Consequences of Wear Debris Clinically? In: Wright, T.M. and Goodman, S.B., Eds., Implant Wear in Total Joint Replacement: Clinical and Biologic Issues, Material and Design Considerations, American Academy of Orthopedic Surgeons, Rosemont, 31-42.

[35] Purdue, P., Koulouvaris, P., Nestor, B. and Sculco, T. (2006) The Central Role of Wear Debris in Periprosthetic Osteolysis. HSS Journal, 2, 102-113. http://dx.doi.org/10.1007/s11420-006-9003-6

[36] Meldrum, R.D., Wurtz, L.D., Feinberg, J.R. and Capello, W.N. (2005) Does Smoking Affect Implant Survivorship in Total Hip Arthroplasty? A Preliminary Retrospective Case Series. The Iowa Orthopaedic Journal, 25, 17-24.

[37] Santaguida, P.L., Hawker, G.A., Hudak, P.L., Glazier, R., Mahomed, N.N., Kreder, H.J., Coyte, P.C. and Wright, J.G. (2008) Patient Characteristics Affecting the Prognosis of Total Hip and Knee Joint Arthroplasty: A Systematic Review. Canadian Journal of Surgery, 51, 428-436.

[38] Nixon, M., Taylor, G., Sheldon, P., Iqbal, S.J. and Harper, W. (2007) Does Bone Quality Predict Loosening of Cemented Total Hip Replacements? The Journal of Bone and Joint Surgery (British volume), 89-B, 1303-1308. http://dx.doi.org/10.1302/0301-620X.89B10.19038

[39] Abdul Kadir, M. and Kamsah, N. (2009) The Effect of Bone Properties due to Skeletal Diseases on Stability of Cementless Hip Stems. American Journal of Applied Sciences, 6, 1988-1994. http://dx.doi.org/10.3844/ajassp.2009.1988.1994

[40] Delforge, G. (2002) Soft Tissue Connective Repair. Musculoskeletal Trauma: Implications for Sports Injury Management, Human Kinetics, Champaign, 44.

[41] Albrektsson, T. and Albrektsson, B. (1987) Osseointegration of Bone Implants. A Review of an Alternative Mode of Fixation. Acta Orthopaedica Scandinavica, 58, 567-577.

[42] Eriksson, A.R. and Albrektsson, T. (1983) Temperature Threshold Levels for Heat-Induced Bone Tissue Injury: A Vital- 
Microscopic Study in the Rabbit. Journal of Prosthetic Dentistry, 50, 101-107. http://dx.doi.org/10.1016/0022-3913(83)90174-9

[43] Sela, J., Gross, U.M., Kohavi, D., Shani, J., Dean, D.D., Boyan, B.D. and Schwartz, Z. (2000) Primary Mineralization at the Surfaces of Implants. Critical Reviews in Oral Biology \& Medicine, 11, 423-436. http://dx.doi.org/10.1177/10454411000110040301

[44] Rafel, S.S. (1962) Temperature Changes during High-Speed Drilling on Bone. Journal of Oral Surgery, Anesthesia, and Hospital Dental Service, 20, 475-477.

[45] Williams, D.F. (1982) Biocompatibility of Orthopedic Implants. Volume I. In: Williams, D.F., Ed., CRC Series in Biocompatibility, CRC Press, Liverpool, 141-195.

[46] Ling, R.S. (1986) Observations on the Fixation of Implants to the Bony Skeleton. Clinical Orthopaedics and Related Research, 210, 80-96.

[47] Wooley, P.H., Nasser, S. and Fitzgerald Jr., R.H. (1996) The Immune Response to Implant Materials in Humans. Clinical Orthopaedics \& Related Research, 326, 63-70. http://dx.doi.org/10.1097/00003086-199605000-00008

[48] Bergmann, G., Deuretzbacher, G., Heller, M., Graichen, F., Rohlmann, A., Strauss, J. and Duda, G.N. (2001) Hip Contact Forces and Gait Patterns from Routine Activities. Journal of Biomechanics, 34, 859-871. http://dx.doi.org/10.1016/S0021-9290(01)00040-9

[49] Ducheyne, P., Willems, G., Martens, M. and Helsen, J. (1984) In Vivo Metal-Ion Release from Porous Titanium-Fiber Material. Journal of Biomedical Materials Research, 18, 293-308. http://dx.doi.org/10.1002/jbm.820180306

[50] Rae, T. (1981) The Toxicity of Metals Used in Orthopaedic Prostheses. An Experimental Study Using Cultured Human Synovial Fibroblasts. Journal of Bone and Joint Surgery, 63-B, 435-440.

[51] MacDonald, S.J. (2004) Can a Safe Level for Metal Ions in Patients with Metal-On-Metal Total Hip Arthroplasties be Determined? Journal of Arthroplasty, 19, 71-77. http://dx.doi.org/10.1016/j.arth.2004.09.008

[52] Dannenmaier, W.C., Haynes, D.W. and Nelson, C.L. (1985) Granulomatous Reaction and Cystic Bony Destruction Associated with High Wear Rate in a Total Knee Prosthesis. Clinical Orthopaedics and Related Research, 198, 224230.

[53] Tallroth, K., Eskola, A., Santavirta, S., Konttinen, Y.T. and Lindholm, T.S. (1989) Aggressive Granulomatous Lesions after Hip Arthroplasty. Journal of Bone and Joint Surgery, 71, 571-575.

[54] Amstutz, H.C., Campbell, P., Kossovsky, N. and Clarke, I.C. (1992) Mechanism and Clinical Significance of Wear Debris-Induced Osteolysis. Clinical Orthopaedics and Related Research, 276, 7-18.

[55] Goodfellow, J. (1992) Malignancy and Joint Replacement. Journal of Bone and Joint Surgery (British volume), 74-B, 645.

[56] Apley, A.G. (1989) Malignancy and Joint Replacement: The Tip of an Iceberg? Journal of Bone and Joint Surgery, 71-B, 1.

[57] Black, J. (1988) Does Corrosion Matter? Journal of Bone and Joint Surgery (British volume), 70-B, 517-520.

[58] Hamblen, D.L. and Carter, R.L. (1984) Sarcoma and Joint Replacement. Journal of Bone and Joint Surgery, 66-B, 625-626.

[59] Penman, H.G. and Ring, P.A. (1984) Osteosarcoma in Association with Total Hip Replacement. Journal of Bone and Joint Surgery, 66-B, 632-634.

[60] Bagó-Granell, J., Aguirre-Canyadell, M., Nardi, J. and Tallada, N. (1984) Malignant Fibrous Histiocytoma of Bone at the Site of a Total Hip Arthroplasty. Journal of Bone and Joint Surgery, 66-B, 38-40.

[61] Jasty, M., Jiranek, W. and Harris, W.H. (1992) Acrylic Fragmentation in Total Hip Replacements and Its Biological Consequences. Clinical Orthopaedics and Related Research, 285, 116-128.

[62] Khan, W.S., Agarwal, M., Malik, A.A., Cox, A.G., Denton, J. and Holt, E.M. (2008) Chromium, Cobalt and Titanium Metallosis Involving a Nottingham Shoulder Replacement. Journal of Bone and Joint Surgery (British volume), 90, 502-505. http://dx.doi.org/10.1302/0301-620X.90B4.20302

[63] Albrektsson, T., Branemark, I.I., Hansson, H.A. and Lindstrom, J. (1981) Osseointegrated Titanium Implants. Acta Orthopaedica, 52, 155-170. http://dx.doi.org/10.3109/17453678108991776

[64] Meyer, U., Joos, U., Mythili, J., Stamm, T., Hohoff, A., Fillies, T., Stratmannc, U. and Wiesmann, H.P. (2004) Ultrastructural Characterization of the Implant/Bone Interface of Immediately Loaded Dental Implants. Biomaterials, 25, 1959-1967. http://dx.doi.org/10.1016/j.biomaterials.2003.08.070

[65] Albrektsson, T. and Linder, L. (1984) Bone Injury Caused by Curing Bone Cement. An in Vivo Study in Rabbit Tibia. Clinical Orthopaedics and Related Research, 183, 280.

[66] Laing, P.G., Ferguson Jr., A.B. and Hodge, E.S. (1967) Tissue Reaction in Rabbit Muscle Exposed to Metallic Implants. Journal of Biomedical Materials Research, 1, 135-149. http://dx.doi.org/10.1002/jbm.820010113 
[67] Nkenke, E., Lehner, B., Weinzierl, K., Thams, U., Neugebauer, J., Steveling, H., Radespiel-Tröger, M. and Neukam, F.W. (2003) Bone Contact, Growth, and Density around Immediately Loaded Implants in the Mandible of Mini Pigs. Clinical Oral Implants Research, 14, 312-321. http://dx.doi.org/10.1034/j.1600-0501.2003.120906.x

[68] Piattelli, A., Corigliano, M., Scarano, A., Costigliola, G. and Paolantonio, M. (1998) Immediate Loading of Titanium Plasma-Sprayed Implants: An Histologic Analysis in Monkeys. Journal of Periodontology, 69, 321-327. http://dx.doi.org/10.1902/jop.1998.69.3.321

[69] Szmukler-Moncler, S., Salama, H., Reingewirtz, Y. and Dubruille, J.H. (1998) Timing of Loading and Effect of Micromotion on Bone-Dental Implant Interface: Review of Experimental Literature. Journal of Biomedical Materials Research, 43, 192-203. http://dx.doi.org/10.1002/(SICI)1097-4636(199822)43:2<192::AID-JBM14>3.0.CO;2-K

[70] Slaets, E., Carmeliet, G., Naert, I. and Duyck, J. (2007) Early Trabecular Bone Healing around Titanium Implants: A Histologic Study in Rabbits. Journal of Periodontology, 78, 510-517. http://dx.doi.org/10.1902/jop.2007.060183

[71] Vandamme, K., Naert, I., Vander Sloten, J., Puers, R. and Duyck, J. (2008) Effect of Implant Surface Roughness and Loading on Peri-Implant Bone Formation. Journal of Periodontology, 79, 150-157. http://dx.doi.org/10.1902/jop.2008.060413

[72] Bloebaum, R.D., Rubman, M.H. and Hofmann, A.A. (1992) Bone Ingrowth into Porous-Coated Tibial Components Implanted with Autograft Bone Chips: Analysis of Ten Consecutively Retrieved Implants. Journal of Arthroplasty, 7, 483-493. http://dx.doi.org/10.1016/S0883-5403(06)80069-0

[73] Hacking, S.A., Bobyn, J.D., Toh, K., Tanzer, M. and Krygier, J.J. (2000) Fibrous Tissue Ingrowth and Attachment to Porous Tantalum. Journal of Biomedical Materials Research, 52, 631-638. http://dx.doi.org/10.1002/1097-4636(20001215)52:4<631::AID-JBM7>3.0.CO;2-6

[74] Hofmann, A.A., Bloebaum, R.D. and Bachus, K.N. (1997) Progression of Human Bone Ingrowth into Porous-Coated Implants. Acta Orthopaedica, 68, 161-166. http://dx.doi.org/10.3109/17453679709004000

[75] Pilliar, R.M., Lee, J.M. and Maniatopoulos, C. (1986) Observations on the Effect of Movement on Bone Ingrowth into Porous-Surfaced Implants. Clinical Orthopaedics and Related Research, 208, 108-113.

[76] Kieswetter, K., Schwartz, Z., Dean, D.D. and Boyan, B.D. (1996) The Role of Implant Surface Characteristics in the Healing of Bone. Critical Reviews in Oral Biology \& Medicine, 7, 329-345. http://dx.doi.org/10.1177/10454411960070040301

[77] Branemark, P.I. and Albrektsson, T. (1982) Titanium Implants Permanently Penetrating Human Skin. Journal of Plastic Surgery and Hand Surgery, 16, 17-21. http://dx.doi.org/10.3109/02844318209006565

[78] Bloebaum, R.D., Bachus, K.N., Rubman, M.H. and Dorr, L.D. (1993) Postmortem Comparative Analysis of Titanium and Hydroxyapatite Porous Coated Femoral Implants Retrieved from the Same Patient. Journal of Arthroplasty, 8, 203-211. http://dx.doi.org/10.1016/S0883-5403(09)80014-4

[79] Vandamme, K., Naert, I., Geris, L., Sloten, J.V., Puers, R. and Duyck, J. (2007) Histodynamics of Bone Tissue Formation around Immediately Loaded Cylindrical Implants in the Rabbit. Clinical Oral Implants Research, 18, 471-480. http://dx.doi.org/10.1111/j.1600-0501.2007.01339.x

[80] Uhthoff, H.K. and Germain, J.P. (1977) The Reversal of Tissue Differentiation around Screws. Clinical Orthopaedics and Related Research, 123, 248-252.

[81] Meyer, A.E., Baier, R.E., Natiella, J.R. and Meenaghan, M.A. (1988) Investigation of Tissue/Implant Interactions during the First Two Hours of Implantation. The Journal of Oral Implantology, 14, 363-379.

[82] Novaes Jr., A.B., Souza, S.L., Barros, R.R., Pereira, K.K., Iezzi, G. and Piattelli, A. (2010) Influence of Implant Surfaces on Osseointegration. Brazilian Dental Journal, 21, 471-481.

[83] Boyan, B.D., Lohmann, C.H., Dean, D., Sylvia, V.L., Cochran, D.L. and Schwartz, Z. (2001) Mechanisms Involved In Osteoblast Response to Implant Surface Morphology. Annual Review of Materials Research, 31, 357-371. http://dx.doi.org/10.1146/annurev.matsci.31.1.357

[84] Bobyn, J.D., Pilliar, R.M., Cameron, H.U. and Weatherly, G.C. (1980) The Optimum Pore Size for the Fixation of Porous-Surfaced Metal Implants by the Ingrowth of Bone. Clinical Orthopaedics and Related Research, 150, $263-270$.

[85] Brady, R.A., Leid, J.G., Calhoun, J.H., Costerton, J.W. and Shirtliff, M.E. (2007) Osteomyelitis and the Role of Biofilms in Chronic Infection. FEMS Immunology \& Medical Microbiology, 52, $13-22$. http://dx.doi.org/10.1111/j.1574-695X.2007.00357.x

[86] Costerton, J.W. (2005) Biofilm Theory Can Guide the Treatment of Device-Related Orthopaedic Infections. Clinical Orthopaedics and Related Research, 437, 7-11. http://dx.doi.org/10.1097/00003086-200508000-00003

[87] Costerton, J.W., Geesey, G.G. and Cheng, K.J. (1978) How Bacteria Stick. Scientific American, 238, 86-95. http://dx.doi.org/10.1038/scientificamerican0178-86

[88] Geesey, G.G., Richardson, W.T., Yeomans, H.G., Irvin, R.T. and Costerton, J.W. (1977) Microscopic Examination of 
Natural Sessile Bacterial Populations from an Alpine Stream. Canadian Journal of Microbiology, 23, 1733-1736. http://dx.doi.org/10.1139/m77-249

[89] Gristina, A.G. and Costerton, J.W. (1984) Bacteria-Laden Biofilms: A Hazard to Orthopedic Prostheses. Infections in Surgery, 3, 655-662.

[90] Lawrence, J.R., Korber, D.R., Hoyle, B.D., Costerton, J.W. and Caldwell, D.E. (1991) Optical Sectioning of Microbial Biofilms. Journal of Bacteriology, 173, 6558-6567.

[91] Marrie, T., Nelligan, J. and Costerton, J.A. (1982) Scanning and Transmission Electron Microscopic Study of an Infected Endocardial Pacemaker Lead. Circulation, 66, 1339-1341. http://dx.doi.org/10.1161/01.CIR.66.6.1339

[92] Nickel, J.C., Ruseska, I., Wright, J.B. and Costerton, J.W. (1985) Tobramycin Resistance of Pseudomonas aeruginosa Cells Growing as a Biofilm on Urinary Catheter Material. Antimicrobial Agents and Chemotherapy, 27, 619-624. http://dx.doi.org/10.1128/AAC.27.4.619

[93] ZoBell, C.E. (1943) The Effect of Solid Surfaces upon Bacterial Activity. Journal of Bacteriology, 46, 39-56.

[94] Costerton, J., Stewart, P. and Greenberg, E. (1999) Bacterial Biofilms: A Common Cause of Persistent Infections. Science, 284, 1318-1322. http://dx.doi.org/10.1126/science.284.5418.1318

[95] James, G.A., Swogger, E., Wolcott, R., Pulcini, E.D., Secor, P., Sestrich, J., Costerton, J.W. and Stewart, P.S. (2008) Biofilms in Chronic Wounds. Wound Repair and Regeneration, 16, 37-44. http://dx.doi.org/10.1111/j.1524-475X.2007.00321.x

[96] Williams, D.L. and Costerton, J.W. (2011) Using Biofilms as Initial Inocula in Animal Models of Biofilm-Related Infections. Journal of Biomedical Materials Research. Part B, 100, 1163-1169.

[97] Costerton, J.W. (2007) The Microbiology of the Healthy Human Body. In: Costerton, J.W., Ed., The Biofilm Primer, Springer, Heidelberg, 107-128. http://dx.doi.org/10.1007/978-3-540-68022-2 4

[98] van der Borden, A.J., van der Werf, H., van der Mei, H.C. and Busscher, H.J. (2004) Electric Current-Induced Detachment of Staphylococcus epidermidis Biofilms from Surgical Stainless Steel. Applied and Environmental Microbiology, 70, 6871-6874. http://dx.doi.org/10.1128/AEM.70.11.6871-6874.2004

[99] Charnley, J. (1972) Postoperative infection after Total Hip Replacement with Special Reference to Air Contamination in the Operating Room. Clinical Orthopaedics and Related Research, 87, 167-187. http://dx.doi.org/10.1097/00003086-197209000-00020

[100] Nelson, C.L., McLaren, A.C., McLaren, S.G., Johnson, J.W. and Smeltzer, M.S. (2005) Is Aseptic Loosening Truly Aseptic? Clinical Orthopaedics and Related Research, 437, 25-30. http://dx.doi.org/10.1097/01.blo.0000175715.68624.3d

[101] Uchida, K., Yayama, T., Kokubo, Y., Miyazaki, T., Nakajima, H., Negoro, K., Takeno, K., Mwaka, E.S., Orwotho, N.T., Shimadzu, M., Kobayashi, S. and Baba, H. (2009) Direct Detection of Pathogens in Osteoarticular Infections by Polymerase Chain Reaction Amplification and Microarray Hybridization. Journal of Orthopaedic Science, 14, 471-483. http://dx.doi.org/10.1007/s00776-009-1373-4

[102] Harris, K.A., Fidler, K.J., Hartley, J.C., Vogt, J., Klein, N.J., Monsell, F. and Novelli, V.M. (2002) Unique Case of Helicobacter sp. Osteomyelitis in an Immunocompetent Child Diagnosed by Broad-Range 16s PCR. Journal of Clinical Microbiology, 40, 3100-3103. http://dx.doi.org/10.1128/JCM.40.8.3100-3103.2002

[103] Stoodley, P., Nistico, L., Johnson, S., Lasko, L.A., Baratz, M., Gahlot, V., Ehrlich, G.D. and Kathju, S. (2008) Direct Demonstration of Viable Staphylococcus aureus Biofilms in an Infected Total Joint Arthroplasty: A Case Report. Journal of Bone and Joint Surgery, 90, 1751-1758.

[104] Blenkinsopp, S.A., Khoury, A.E. and Costerton, J.W. (1992) Electrical Enhancement of Biocide Efficacy against Pseudomonas Aeruginosa Biofilms. Applied and Environmental Microbiology, 58, 3770-3773.

[105] Patel, R., Osmon, D.R. and Hanssen, A.D. (2005) The Diagnosis of Prosthetic Joint Infection: Current Techniques and Emerging Technologies. Clinical Orthopaedics and Related Research, 437, 55-58. http://dx.doi.org/10.1097/01.blo.0000175121.73675.fd

[106] van der Borden, A.J., Maathuis, P.G., Engels, E., Rakhorst, G., van der Mei, H.C., Busscher, H.J. and Sharma, P.K. (2007) Prevention of Pin Tract Infection in External Stainless Steel Fixator Frames Using Electric Current in a Goat Model. Biomaterials, 28, 2122-2126. http://dx.doi.org/10.1016/j.biomaterials.2007.01.001

[107] van der Borden, A.J., van der Mei, H.C. and Busscher, H.J. (2005) Electric Block Current Induced Detachment from Surgical Stainless Steel and Decreased Viability of Staphylococcus epidermidis. Biomaterials, 26, 6731-6735. http://dx.doi.org/10.1016/j.biomaterials.2004.04.052

[108] Hetrick, E.M. and Schoenfisch, M.H. (2006) Reducing Implant-Related Infections: Active Release Strategies. Chemical Society Reviews, 35, 780-790. http://dx.doi.org/10.1039/b515219b

[109] Williams, D.L., Haymond, B.S., Beck, J.P., Savage, P.B., Chaudhary, V., Epperson, R.T., Kawaguchi, B. and Bloe- 
baum, R.D. (2012) In Vivo Efficacy of a Silicone-Cationic Steroid Antimicrobial Coating to Prevent Implant-Related Infection. Biomaterials, 33, 8641-8656. http://dx.doi.org/10.1016/j.biomaterials.2012.08.003

[110] Darouiche, R.O. (2007) Antimicrobial Coating of Devices for Prevention of Infection: Principles and Protection. The International Journal of Artificial Organs, 30, 820-827.

[111] Kalicke, T., Schierholz, J., Schlegel, U., Frangen, T.M., Koller, M., Printzen, G., et al. (2006) Effect on Infection Resistance of a Local Antiseptic and Antibiotic Coating on Osteosynthesis Implants: An in Vitro and in Vivo Study. Journal of Orthopaedic Research, 24, 1622-1640. http://dx.doi.org/10.1002/jor.20193

[112] Lockwood, N., Hergenrother, R., Patrick, L., Stucke, S., Steendam, R., Pacheco, E., Virmani, R., Kolodgie, F.D. and Hubbard, B. (2010) In Vitro and in Vivo Characterization of Novel Biodegradable Polymers for application as DrugEluting Stent Coatings. Journal of Biomaterials Science, Polymer Edition, 21, 529-552. http://dx.doi.org/10.1163/156856209X429175

[113] Lucke, M., Schmidmaier, G., Sadoni, S., Wildemann, B., Schiller, R., Haas, N.P. and Raschke, M. (2003) Gentamicin Coating of Metallic Implants Reduces Implant-Related Osteomyelitis in Rats. Bone, 32, 521-531. http://dx.doi.org/10.1016/S8756-3282(03)00050-4

[114] Sinclair, K.D., Farnsworth, R.J., Loc-Carrillo, C., Williams, D.L. and Bloebaum, R.D. (2012) Model Development for Determining the Efficacy of a Combination Coating for the Prevention Perioperative Device Related Infections: A Pilot Study. Journal of Biomedical Materials Research. Part B, 101, 1143-1153.

[115] Sinclair, K.D., Pham, T.X., Farnsworth, R.W., Williams, D.L., Loc-Carrillo, C., Horne, L.A., Ingebretsen, S.H. and Bloebaum, R.D. (2012) Development of a Broad Spectrum Polymer-Released Antimicrobial Coating for the Prevention of Resistant Strain Bacterial Infections. Journal of Biomedical Materials Research. Part A, 100, 2732-2738. http://dx.doi.org/10.1002/jbm.a.34209

[116] Williams, D.L., Sinclair, K.D., Jeyapalina, S. and Bloebaum, R.D. (2012) Characterization of a Novel Active Release Coating to Prevent Biofilm Implant-Related Infections. Journal of Biomedical Materials Research. Part B, 101, 10781089.

[117] Zhao, L., Chu, P.K., Zhang, Y. and Wu, Z. (2009) Antibacterial Coatings on Titanium Implants. Journal of Biomedical Materials Research Part B, 91B, 470-480. http://dx.doi.org/10.1002/jbm.b.31463 